\title{
Fate of selenium in biofortification of wheat on calcareous soil: an isotopic study
}

\author{
Saeed Ahmad • Elizabeth H. Bailey (1) - Muhammad Arshad - Sher Ahmed • \\ Michael J. Watts $\cdot$ Scott D. Young
}

Received: 31 August 2020/Accepted: 27 January 2021/Published online: 25 February 2021

(C) The Author(s) 2021

\begin{abstract}
Selenium (Se) biofortification of staple cereal crops can improve the Se nutritional status of populations. A field trial employing an enriched stable isotope of Se $\left({ }^{77} \mathrm{Se}\right)$ was undertaken over three consecutive cropping seasons in a coarse-textured, calcareous soil in Gilgit-Baltistan, Pakistan. The objectives were to (1) assess the feasibility and efficiency of Se biofortification, (2) determine the fate of residual $\mathrm{Se}$, and (3) assess the consequences for dietary Se intake. Isotopically enriched ${ }^{77} \mathrm{Se}\left({ }^{77} \mathrm{Se}_{\mathrm{Fert}}\right)$ was applied, either as selenate or as selenite, at three levels $\left(0,10\right.$, and $\left.20 \mathrm{~g} \mathrm{ha}^{-1}\right)$ to a wheat crop. Residual ${ }^{77} \mathrm{Se}_{\mathrm{Fert}}$ availability was assessed in subsequent crops of maize and wheat without further ${ }^{77} \mathrm{Se}_{\mathrm{Fert}}$ addition.
\end{abstract}

Supplementary Information The online version contains supplementary material available at https://doi.org/10.1007/ s10653-021-00841-1.

S. Ahmad · E. H. Bailey $(\bowtie) \cdot$ S. D. Young

Division of Agricultural and Environmental Sciences,

School of Biosciences, University of Nottingham, Sutton

Bonington Campus, Loughborough,

Leicestershire LE12 5RD, UK

e-mail: liz.bailey@nottingham.ac.uk

M. Arshad - S. Ahmed

Pakistan Agricultural Research Council - Mountain

Agricultural Research Centre, Gilgit-Baltistan, Pakistan

\section{J. Watts}

British Geological Survey, Centre for Environmental

Geochemistry, Inorganic Geochemistry,

Nottingham NG12 5GG, UK
Loss of ${ }^{77} \mathrm{Se}_{\text {Fert }}$ was c. $35 \%$ by the first (wheat) harvest, for both selenium species, attributable to the practice of flood irrigation and low adsorption capacity of the soil. No ${ }^{77} \mathrm{Se}_{\text {Fert }}$ was detectable in subsequent maize or wheat crops. The remaining ${ }^{77} \mathrm{Se}_{\mathrm{Fert}}$ in soil was almost entirely organically bound and diminished with time following a reversible (pseudo-)first-order trend. Thus, repeat applications of Se would be required to adequately biofortify grain each year. In contrast to native soil $\mathrm{Se}$, there was no transfer of ${ }^{77} \mathrm{Se}_{\text {Fert }}$ to a recalcitrant form. Grain from control plots would provide only $0.5 \mu \mathrm{g}$ person $^{-1}$ day $^{-1}$ of Se. By contrast, a single application of $20 \mathrm{~g} \mathrm{ha}^{-1} \mathrm{Se}^{\mathrm{VI}}$ could provide c. $47 \mu \mathrm{g}^{\text {person }}{ }^{-1}$ day $^{-1} \mathrm{Se}$ in wheat, sufficient to avoid deficiency when combined with dietary Se intake from other sources (c. $25 \mu \mathrm{g} \mathrm{day}^{-1}$ ).

Keywords Selenium - Biofortification - Wheat . Stable isotopes $\cdot$ Residual Se

\section{Background}

Selenium (Se) is a crucial dietary micronutrient for human health, but half a billion people worldwide are at risk of Se deficiency (Combs 2001; FairweatherTait et al. 2011; Ligowe et al. 2020a). It is a vital component of many selenoproteins (Brown and Arthur 2001; Antonyak et al. 2018) which play an important role in regulating various body functions, such as 
metabolism of thyroid hormones and protecting cells from damage by free radicals (Rayman 2000, 2012; Yang et al. 2017). Its deficiency is associated with various health disorders such as cardiovascular diseases, cancer, and reduced fertility (Tinggi 2008; Fairweather-Tait et al. 2011; Zhang et al. 2020). The main sources of Se for humans and animals are foods such as cereals, poultry, meat, and fish; contributions from drinking water and other non-food sources are nominal (Rayman 2008; Joy et al. 2015a, b).

In intermediate and low-income countries, cereals provide a large proportion (50-80\%) of daily calorific intake (WHO 2019). In Pakistan, cereals, primarily wheat, account for $75 \%$ of the energy supply in an average daily diet (Zia et al. 2014). However, it is suspected that the Se concentration in wheat from Gilgit-Baltistan is normally insufficient to meet the WHO-recommended daily allowance (RDA) of Se (50-70 $\mu \mathrm{g} \mathrm{day}^{-1}$ ) for an adult (Ahmad 2020). The average concentration of Se in locally grown wheat has been reported to be $29 \mu \mathrm{g} \mathrm{kg}^{-1}$ (Ahmad 2020) which would supply $<20 \%\left(8.67 \mu \mathrm{g} \mathrm{Se} \mathrm{day}^{-1}\right)$ of the Se RDA. Deficiency of Se in human populations can be addressed in multiple ways, such as taking $\mathrm{Se}$ supplements, dietary diversification, food fortification, and crop biofortification through agronomic or genetic interventions (White and Broadley 2009; Broadley et al. 2006, 2010; Chilimba et al. 2011). Most of these strategies have various shortcomings associated with them, while the efficacy of others, such as crop improvement and genetic modification, is not yet clear (White and Broadley 2009; White 2016). However, in the case of Pakistan, particularly GilgitBaltistan where the population is largely dependent on indigenous agricultural produce (Rasul and Hussain 2015), crop biofortification is the most feasible approach. Furthermore, crop biofortification with fertilisers can easily enhance plant Se content (Broadley et al. 2010; Mao et al. 2014) and has been tested successfully in other countries, such as the UK, Finland, and Malawi (Broadley et al. 2010; Alfthan et al. 2015; Ligowe et al. 2019). Finland adopted crop biofortification in the 1980s with Se-enriched fertilisers and successfully enhanced Se concentration in the Finnish food supply (Broadley et al. 2006; Alfthan et al. 2015). The efficiency of Se biofortification is likely to vary with climatic conditions, agricultural practices, and soil type (Ebrahimi et al. 2019).
Therefore, experience gained in other countries may not be applicable to the study area of this project.

Inorganic Se species, selenite $\left(\mathrm{Se}^{\mathrm{IV}}\right)$ and selenate $\left(\mathrm{Se}^{\mathrm{VI}}\right)$, are both available for plant uptake (Broadley et al. 2006; Li et al. 2008). Selenate is normally used for biofortification because it is more soluble and hence more bioavailable (Chilimba et al. 2012a; Ligowe et al. 2020b), but it is also more prone to leaching, particularly in coarse-textured soils at high $\mathrm{pH}$. It is recognised that soils in Gilgit-Baltistan are largely coarse-textured and calcareous with a high $\mathrm{pH}$ (>7) (Hashmi and Shafiullah 2003). Selenite is normally less efficient in biofortification as it is sorbed strongly by soil $\mathrm{Fe}$ oxides and rapidly transferred to humus-bound forms ( $\mathrm{Li}$ et al. 2008; Ligowe et al. 2019). However, adsorption on Fe oxides in calcareous soils is likely to be weak considering the likely trend in the $\mathrm{Se}^{\mathrm{IV}}$ adsorption envelope $\left(\mathrm{H}_{2} \mathrm{SeO}_{3}\right.$, $\mathrm{HSeO}_{3}{ }^{-}, \mathrm{SeO}_{3}{ }^{2-} ; \mathrm{pKa}_{1}=2.47, \mathrm{pKa}_{2}=7.31$ ). It is possible that high $\mathrm{pH}$ might ensure continued bioavailability of 'residual' $\mathrm{Se}$-i.e. fertiliser-derived $\mathrm{Se}$ $\left(\mathrm{Se}_{\mathrm{Fert}}\right)$ remaining in the soil for following crops in subsequent growing seasons.

This study aimed to understand the efficiency of Se biofortification in cereal crops with a single application of Se inorganic species $\left(\mathrm{Se}^{\mathrm{IV}}\right.$ and $\left.\mathrm{Se}^{\mathrm{VI}}\right)$. The objectives of this study were to: (1) study the feasibility and efficiency of Se biofortification using a single application to wheat of an enriched ${ }^{77} \mathrm{Se}$ stable isotope to discriminate between soil-derived and fertiliser-derived Se $\left({ }^{77} \mathrm{Se}_{\mathrm{Fert}}\right)$; (2) evaluate the fate of residual ${ }^{77} \mathrm{Se}_{\mathrm{Fert}}$ in a cereal rotation (wheatmaize-wheat), as practised in Gilgit-Baltistan; and (3) assess the consequences of biofortification for dietary Se intake.

\section{Methods}

\section{Overview}

A rotational field trial was undertaken over three consecutive cropping seasons (2017-2018, 2018-2019) in Gilgit-Baltistan. The crops chosen were wheat followed by maize and then wheat in the third growing season. The inorganic Se species, selenite $\left(\mathrm{Se}^{\mathrm{IV}}\right)$ and selenate $\left(\mathrm{Se}^{\mathrm{VI}}\right)$, were applied as isotopically enriched ${ }^{77} \mathrm{Se}$; each species was applied at three different levels $\left(0,10\right.$, and $\left.20 \mathrm{~g} \mathrm{ha}^{-1}\right)$ to the first 
wheat crop in March 2018. After wheat harvest, a maize crop was planted on the site (June 2018), grown, and subsequently sampled (November 2018); a second wheat crop was then planted (December 2018) and harvested (June 2019) as before. Soil was sampled at each harvest and analysed for soluble $\left(\mathrm{Se}_{\mathrm{sol}}\right)$, adsorbed $\left(\mathrm{Se}_{\mathrm{ads}}\right)$, organic $\left(\mathrm{Se}_{\mathrm{TMAH}}\right)$, and total ${ }^{77} \mathrm{Se}\left({ }^{77} \mathrm{Se}_{\mathrm{T}}\right)$; plant analysis included grain and other parts (Mathers et al. 2017; Ligowe et al. 2020b).

\section{Site selection and management}

An agricultural field at the Mountain Agriculture Research Centre (MARC) Gilgit station (35.68157 N, $74.62981 \mathrm{E}$ ) was selected (supplementary material Fig. A1). The total area of the experimental field was $268 \mathrm{~m}^{2}(17.6 \times 15.2 \mathrm{~m})$. Twenty plots $(2 \mathrm{~m} \times 2 \mathrm{~m})$ were established with $0.4 \mathrm{~m}$ between consecutive plots in the central $178 \mathrm{~m}^{2}(14.6 \times 12.2 \mathrm{~m})$ of the experimental field. A discard area of $3 \mathrm{~m}$ was established on all four sides of the selected area which was cultivated in the same way as the rest of the field. Four replicates of each treatment were randomly distributed in a randomised block design. All plots received the same irrigation water and basal fertiliser of $140 \mathrm{~kg} \mathrm{ha}^{-1}$ nitrogen and $80 \mathrm{~kg} \mathrm{ha}^{-1}$ phosphorus as per local practice. Before sowing the first wheat crop, the soil was ploughed and seeds were sown by hand in straight lines in each plot according to the local agriculture practice. However, for sowing the second (maize) and third (wheat) crop the soil was not ploughed and seeds were planted with minimum tillage in all the selected areas.

Preparation and application of ${ }^{77} \mathrm{Se}^{\mathrm{IV}}$ and ${ }^{77} \mathrm{Se}^{\mathrm{VI}}$ solutions

Enriched ${ }^{77} \mathrm{Se}$ treatment solutions of both ${ }^{77} \mathrm{Se}^{\mathrm{IV}}$ and ${ }^{77} \mathrm{Se}^{\mathrm{VI}}$ were prepared from an isotopically enriched stock of elemental ${ }^{77} \mathrm{Se}(150 \mathrm{mg} ; 99.66 \%$ atom $\%$ of ${ }^{77} \mathrm{Se}$ ), purchased from Isoflex, San Francisco, USA, according to the methods described in Mathers et al. (2017). The treatment solution for each field was applied at the early stem extension stage (Zadoks stage 31). The experimental field was flood-irrigated, and two days later when the field was still moist, Se treatment solutions were applied to each plot. For ${ }^{77} \mathrm{Se}$ application, each treatment solution was separately mixed with $6 \mathrm{~L}$ irrigation water in a watering can and then sprayed evenly over the plot $\left(1.5 \mathrm{~L} \mathrm{~m}^{-2}\right)$. Each treatment application was followed by spraying with 6 $\mathrm{L}\left(1.5 \mathrm{~L} \mathrm{~m}^{-2}\right)$ irrigation water from the same container to wash the treatment solution off the crop leaves.

Soil and plant sampling and processing

Soil sampling was undertaken before the experiment started (H0, November 2017) and at the end of each growing season, i.e. following the first wheat harvest (H1, June 2018), the maize harvest $(\mathrm{H} 2$, November 2018), and the second wheat harvest (H3, June 2019). A five-point composite sample of topsoil $(0-20 \mathrm{~cm})$ was collected from each plot using a stainless steel auger. The soil was air-dried and sieved $(<2 \mathrm{~mm})$, and $10 \mathrm{~g}$ of each soil sample was finely ground in an agate ball mill (Retsch PM 400, Haan, Germany) for elemental analysis.

At the end of each growing seasons $(\mathrm{H} 1, \mathrm{H} 2$, and $\mathrm{H} 3$ ), plants were harvested from the central $1 \mathrm{~m}^{2}$ of each plot $(2 \mathrm{~m} \times 2 \mathrm{~m})$ at $5 \mathrm{~cm}$ above the ground with a scythe. Plants were subsampled (10\% of the total) and then air-dried at the MARC Laboratory in Gilgit. Wheat ears were hand-threshed to separate grain and chaff. Maize plants were divided into stems, leaves, husks, and grain. All of the crop samples were separately milled using an ultra-centrifugal mill fitted with a 0.5 -mm stainless steel sieve.

Soil characterisation

Soil $\mathrm{pH}$ was measured using a $\mathrm{pH}$ meter (Hanna, model $\mathrm{pH}$ 209) with combined glass electrode on a soil-water suspension with a ratio (w/v) of 1:2.5 after shaking end-over-end for $30 \mathrm{~min}$ (Rowell 1994). Oxides of $\mathrm{Fe}, \mathrm{Mn}$, and $\mathrm{Al}$ in soil samples were determined in citrate-bicarbonate-dithionate (CBD) extracts of finely ground soil using a single quadrupole ICP-MS (model iCAP-Q, Thermo Scientific, Bremen, Germany). The milled soil was also used for measuring soil organic carbon in a Leco TruMac $\mathrm{CN}$ analyser (Stockport, UK). Acid digestion $\left(\mathrm{HNO}_{3}-\mathrm{HClO}_{4}-\mathrm{HF}\right)$ of finely ground soil was undertaken in PFA vessels using a teflon-coated graphite block digester (Model A3, Analysco Ltd.) controlled by a Eurotherm unit (Mather et al. 2017; Ligowe et al. 2020b). Total selenium concentration $\left(\mathrm{Se}_{\mathrm{T}}\right),{ }^{77} \mathrm{Se}$ isotopes, and other elemental analyses were undertaken using a triple- 
quadrupole ICP-MS (model iCAP-TQ, Thermo Scientific, Bremen, Germany).

A three-stage sequential extraction of $<2 \mathrm{~mm}$ sieved soil was undertaken with (1) potassium nitrate $\left(0.01 \mathrm{M} \mathrm{KNO}_{3}\right)$ followed by (2) potassium dihydrogen phosphate $\left(0.016 \mathrm{M} \mathrm{KH}_{2} \mathrm{PO}_{4}\right)$, and finally (3) $10 \%$ tetramethylammonium hydroxide (TMAH) to determine, respectively, 'soluble' $\left(\mathrm{Se}_{\mathrm{sol}}\right)$, 'adsorbed' $\left(\mathrm{Se}_{\mathrm{ads}}\right)$, and 'organic' $\left(\mathrm{Se}_{\mathrm{TMAH}}\right)$ fractions of soilderived $\mathrm{Se}\left(\mathrm{Se}_{\mathrm{Nat}}\right)$ and residual ${ }^{77} \mathrm{Se}_{\mathrm{Fert}}$ (Ligowe et al. 2020b). TMAH extracts organically bound Se by mobilising the soluble (fulvic) and colloidal (humic) soil organic fractions and also potentially through alkaline hydrolysis of organic Se. Selenium speciation analysis was undertaken on the soluble and adsorbed fractions using an HPLC unit (Dionex ICS-5000) coupled to the ICP-MS. The chromatography eluent consisted of $4.00 \mathrm{~g} \mathrm{~L}^{-1} \mathrm{NH}_{4} \mathrm{NO}_{3}, 20 \mathrm{ml} \mathrm{L}^{-1}$ methanol, $0.00325 \mathrm{~g} \mathrm{~L}^{-1} \mathrm{NH}_{4}$-EDTA, and $12.1 \mathrm{~g} \mathrm{~L}^{-1}$ Tris buffer. The stationary phase used was a Hamilton PRX-100 anion exchange column $(100 \times 4.1 \mathrm{~mm}$; $5 \mu \mathrm{m}$ particle size); the eluent flow rate was $1.4 \mathrm{~mL} \min ^{-1}$.

Plant analysis

Finely ground plant samples (c. $0.2 \mathrm{~g}$ ) were microwave-digested in $6 \mathrm{ml} \mathrm{HNO}_{3}$ (68\% Primar Plus ${ }^{\mathrm{TM}}$ grade). For grain samples, $0.3 \mathrm{~g}$ was digested in $3 \mathrm{ml}$ $\mathrm{HNO}_{3}$ (70\%), $3 \mathrm{ml}$ Milli-Q water, and $2 \mathrm{ml} \mathrm{H}_{2} \mathrm{O}_{2}$ (30\%). The final volume of digested sample was made to $20 \mathrm{ml}$ (plant) and $15 \mathrm{ml}$ (grain). Each digestion batch included nine operational blanks and a certified reference material (CRM) (rice flour standard, NIST $1568 \mathrm{~b}$ ). The mean recovery of Se in the CRM (NIST 1568b) was $96 \%$ (certified value: $365 \mathrm{~g} \mathrm{~kg}^{-1}$, measured value: $351 \pm 1.67 \mu \mathrm{g} \mathrm{kg}^{-1}, n=9$ ). A $1: 10$ dilution with Milli-Q water was done prior to analysis of Se isotopes and multi-elemental analysis via ICPMS (iCAP-TQ).

Processing TQ-ICP-MS ${ }^{77} \mathrm{Se}$ and ${ }^{80} \mathrm{Se}$ intensity data

The raw intensity data of Se isotopes $\left({ }^{77} \mathrm{Se}\right.$ and $\left.{ }^{80} \mathrm{Se}\right)$ were exported as intensity values (counts-per-second; CPS) from the triple quadrupole ICP-MS (iCAP TQ). Both isotopes were measured in $\mathrm{O}_{2}$ cell mode as massshifted to $\mathrm{m} / \mathrm{z} 93\left({ }^{77} \mathrm{Se}^{16} \mathrm{O}\right)$ and $\mathrm{m} / \mathrm{z} 96\left({ }^{80} \mathrm{Se}^{16} \mathrm{O}\right)$ to reduce interferences from $\mathrm{Se}$ and Ge hydrides and the ${ }^{40} \mathrm{Ar}$ dimer. The ${ }^{77} \mathrm{Se}$ intensity signals were also corrected for minor interference at mass $93\left({ }^{76} \mathrm{Ge}^{1-}\right.$ $\left.\mathrm{H}^{16} \mathrm{O}\right)$ by running a $\mathrm{Ge}$ standard $\left(5 \mu \mathrm{g} \mathrm{L}^{-1}\right)$. Drift correction relied on $\mathrm{Rh}$ as an internal standard. Calibration slopes for both isotopes $\left({ }^{77} \mathrm{Se}\right.$ and $\left.{ }^{80} \mathrm{Se}\right)$ were derived from multi-isotope Se calibration standards (SPEX CertiPrep CLMS-2; 1, 2, 5, and $\left.10 \mu \mathrm{g} \mathrm{L}^{-1}\right)$. The concentration of native ${ }^{77} \mathrm{Se}$ in each sample was calculated from the natural isotopic abundance of ${ }^{77} \mathrm{Se}$ and the measured concentration of total (native) $\mathrm{Se}$ (from ${ }^{80} \mathrm{Se}$ ); the ${ }^{77} \mathrm{Se}$ derived from fertiliser $\left(\mathrm{Se}_{\mathrm{Fert}}\right)$ was then obtained by difference.

Modelling the loss of $\mathrm{Se}_{\mathrm{Fert}}$

The loss in $\mathrm{Se}_{\mathrm{Fert}}$ concentration as a function of time was described using a reversible first-order equation (Eq. 1.), adapted from Crout et al. (2006), in which $\mathrm{Se}_{\mathrm{t}}$ is $\mathrm{Se}_{\mathrm{Fert}}$ remaining in soil at time $t, \mathrm{Se}_{0}$ is the original concentration of $\mathrm{Se}_{\mathrm{Fert}}$ added to the soil $\left(\mathrm{g} \mathrm{ha}^{-1}\right), \mathrm{Se}_{\mathrm{Eq}}$ is the 'equilibrium' $\mathrm{Se}_{\mathrm{Fert}}$ remaining at infinite time, and $\mathrm{K}$ is the sum of the forward and reverse rate constants $\left(k_{1}+k_{2}\right)$.

$S e_{t}=S e_{E q}+\left(S e_{0}-S e_{E q}\right) \exp (-K t)$.

\section{Calculation of distribution coefficient}

The distribution coefficient $(k d)$ is the ratio of $\mathrm{Se}_{\mathrm{ads}}$ to $\mathrm{Se}_{\mathrm{sol}}$ and was calculated for both $\mathrm{Se}_{\mathrm{Nat}}$ and $\mathrm{Se}_{\mathrm{Fert}}$, respectively, from Eq. 2:

$k d=\frac{S e_{a d s}}{S e_{s o l}}$

where $\mathrm{Se}_{\mathrm{ads}}$ and $\mathrm{Se}_{\text {sol }}$ are the concentrations of Se in soil $\left(\mu \mathrm{g} \mathrm{kg}^{-1}\right)$ in the 'adsorbed' and 'soluble' fractions.

Calculating bioconcentration factor and bioavailability ratio

The bioconcentration factor (BCF) is formulated as the ratio of $\mathrm{Se}_{\mathrm{Nat}}$ or $\mathrm{Se}_{\mathrm{Fert}}$ in the plant to their respective concentrations in soil and is a convenient index of bioavailability. The BCF values for the wheat crop at $\mathrm{H} 1$ for both species of $\mathrm{Se}_{\mathrm{Fert}}\left(\mathrm{Se}^{\mathrm{IV}}\right.$ and $\left.\mathrm{Se}^{\mathrm{VI}}\right)$ and $\mathrm{Se}_{\mathrm{Nat}}$ were calculated from Eq. 3: 
$S e_{B C F}=\frac{S e_{\text {plant }}}{S e_{\text {soil }}}$.

In Eq. 3, $\mathrm{Se}_{\text {plant }}$ is Se concentration $\left(\mu \mathrm{g} \mathrm{kg}^{-1}\right)$ in each fraction (straw, chaff and grain) of wheat plant, respectively, and $\mathrm{Se}_{\text {soil }}$ is total $\mathrm{Se}_{\mathrm{Nat}}$ or $\mathrm{Se}_{\mathrm{Fert}}$ concentration $\left(\mu \mathrm{g} \mathrm{kg}^{-1}\right)$ in the corresponding soils. The total soil $\mathrm{Se}_{\mathrm{Nat}}$ concentration used in Eq. 3 was measured in the soil HF digests, while the total $\mathrm{Se}_{\mathrm{Fert}}$ concentrations in soil of 4 and $8 \mu \mathrm{g} \mathrm{kg}^{-1}$ were calculated from the application rates of 10 and $20 \mathrm{~g} \mathrm{ha}^{-1}$, respectively, assuming a topsoil mass of $2500 \mathrm{tha}^{-1}$.

The relative bioavailability of $\mathrm{Se}_{\mathrm{Fet}}\left(\mathrm{Se}^{\mathrm{IV}}\right.$ and $\left.\mathrm{Se}^{\mathrm{VI}}\right)$ and $\mathrm{Se}_{\mathrm{Nat}}$ in the $\mathrm{H} 1$ wheat crop was calculated as a 'bioavailability ratio' $\left(B_{\mathrm{R}}\right)$ from Eq. 4 :

$B_{R}=\frac{B C F_{\text {Fert }}}{B C F_{\text {Nat }}}$

where $\mathrm{BCF}_{\mathrm{Fert}}$ represents the bioconcentration factor for fertiliser-derived Se $\left({ }^{77} \mathrm{Se}_{\mathrm{Fert}}\right)$ and $\mathrm{BCF}_{\mathrm{Nat}}$ is the bioconcentration factor for soil-derived $\mathrm{Se}\left(\mathrm{Se}_{\mathrm{Nat}}\right)$ in the plant.

\section{Statistical analysis}

Basic statistical calculations including mean, median, standard deviation, and standard error were performed in Microsoft Excel 2016, while Minitab (version 18.1) was used for the ANOVA.

\section{Results and discussion}

\section{Soil characteristics}

Basic soil characteristics including soil $\mathrm{pH}$ and the concentrations of organic carbon, $\mathrm{CaCO}_{3}$, and metal oxides $\left(\mathrm{Fe}_{2} \mathrm{O}_{3}, \mathrm{MnO}_{2}\right.$, and $\left.\mathrm{Al}(\mathrm{OH})_{3}\right)$ were similar across all the field plots and did not vary significantly (ANOVA, $p>0.05$ ). The mean soil $\mathrm{pH}$ of all plots was $7.84 \pm 0.05$. The soil organic carbon and $\mathrm{CaCO}_{3}$ contents were $1.60 \% \pm 0.103$ and $1.73 \% \pm 0.270$, respectively; the mean concentrations of $\mathrm{Fe}, \mathrm{Mn}$, and $\mathrm{Al}$ oxides were $3.13,0.151$, and $0.738 \mathrm{~g} \mathrm{~kg}^{-1}$, respectively. The mean total soil Se and TMAHextractable Se concentrations were $139 \mu \mathrm{g} \mathrm{kg}^{-1}$ and $94 \mu \mathrm{g} \mathrm{kg}^{-1}$, respectively, suggesting a very low overall Se concentration and the presence of a nonorganic recalcitrant Se phase (c. $45 \mu \mathrm{g} \mathrm{kg}^{-1}$ ).
Fertiliser Se dynamics in soil

The concentration of fertiliser-derived $\mathrm{Se}\left(\mathrm{Se}_{\mathrm{Fert}}\right)$ in soil decreased with time following its application in March 2018 (Table 1). Compared to its original application of 10 and $20 \mathrm{~g} \mathrm{ha}^{-1}$, the average concentration of $\mathrm{Se}_{\mathrm{Fert}}$ had decreased by $30 \%$ and $42 \%$ at wheat harvest (H1; June 2018), by $51 \%$ and $62 \%$ at maize harvest (H2; November 2018) and by $60 \%$ and $82 \%$ at the second wheat harvest (H3; June 2019) (Fig. 1). There was no significant difference in the proportion of $\mathrm{Se}_{\mathrm{Fert}}$ lost between the four treatments at any of the three harvests (ANOVA, $p>0.05$ ).

The decrease in $\mathrm{Se}_{\mathrm{Fert}}$ concentration at $\mathrm{H} 1$ can be attributed to the combined effects of plant uptake and loss of Se from the soil through leaching or volatilisation. The losses due to plant uptake at $\mathrm{H} 1$ were low and varied between treatments and application levels. For $\mathrm{Se}^{\mathrm{IV}}$, removal by the crop was $1.36 \%$ and $1.46 \%$ at $10 \mathrm{~g} \mathrm{ha}^{-1}$ and $20 \mathrm{~g} \mathrm{ha}^{-1}$, respectively; equivalent figures for $\mathrm{Se}^{\mathrm{VI}}$ were greater, at $3.34 \%$ and $4.32 \%$, which reflects the greater bioavailability of selenate. The minor contribution to ${ }^{77} \mathrm{Se}_{\mathrm{Fert}}$ loss by crop uptake at $\mathrm{H} 1$ suggests that ${ }^{77} \mathrm{Se}_{\mathrm{Fert}}$ was lost either through volatilisation or through leaching in irrigation water due to irrigation shortly after application of ${ }^{77} \mathrm{Se}_{\mathrm{Fert}}$. It has been reported that volatilisation of Se accounts for a small proportion $(6.1 \%)$ of Se loss from sediments (Karlson and Frankenberger 1990). Hence, it is reasonable to assume that flood irrigation (widely practiced locally) was the main cause of loss of ${ }^{77} \mathrm{Se}_{\mathrm{Fert}}$, especially as the soil has a high $\mathrm{pH}$ which limits the retention of $\mathrm{Se}$ on $\mathrm{Fe}$ oxides. Surprisingly, the difference in total loss between $\mathrm{Se}^{\mathrm{IV}}$ and $\mathrm{Se}^{\mathrm{VI}}$, mainly due to leaching, was quite small which again may reflect the high $\mathrm{pH}$ of the soil at which $\mathrm{Se}^{\mathrm{IV}}$ adsorption is comparatively weak. Further loss of ${ }^{77} \mathrm{Se}_{\text {Fert }}$, measured at $\mathrm{H} 2$ and $\mathrm{H} 3$, was not due to plant uptake because ${ }^{77} \mathrm{Se}_{\mathrm{Fert}}$ in $\mathrm{H} 2$ and $\mathrm{H} 3$ crops was below the detection limit for ${ }^{77} \mathrm{Se}$ (c. $0.25 \mu \mathrm{g} \mathrm{kg}{ }^{-1}$ ). Continued losses of ${ }^{77} \mathrm{Se}_{\mathrm{Fert}}$ from the soil through leaching may be particularly likely in these soils because of their high $\mathrm{pH}$, coarse texture, and low organic carbon content $(1.6 \%)$; these are all characteristics which will reduce the ability of the soil to retain added Se (GisselNielsen and Hamdy 1977; Moreno et al. 2013; Lopes et al. 2017).

Speciation analysis of post-H1 soils demonstrated that the only inorganic form of ${ }^{77} \mathrm{Se}_{\mathrm{Fert}}$ present in the 
Table 1 Status of fertiliser Se $\left({ }^{77} \mathrm{Se}_{\mathrm{Fert}}\right)$ in the soil after each harvest (wheat harvest $=\mathrm{H} 1$, maize harvest $=\mathrm{H} 2$, second wheat harvest $=\mathrm{H} 3$ ). Concentrations presented are the average of four replicate plots

\begin{tabular}{|c|c|c|c|c|c|c|c|c|c|}
\hline \multirow[t]{2}{*}{$\begin{array}{l}\text { Treatment types and level of application } \\
\left(\mathrm{g} \mathrm{ha}^{-1}\right)^{\mathrm{a}}\end{array}$} & \multicolumn{3}{|c|}{ Plant uptake $\left(\mathrm{g} \mathrm{ha}^{-1}\right)$} & \multicolumn{3}{|c|}{$\begin{array}{l}{ }^{77} \mathrm{Se}_{\mathrm{Fert}} \text { remaining in soil } \\
\left(\mathrm{g} \mathrm{ha}^{-1}\right) \text { (percentage recovery in } \\
\text { brackets) }\end{array}$} & \multicolumn{3}{|c|}{ Total loss $\left(\mathrm{g} \mathrm{ha}^{-1}\right)$} \\
\hline & $\mathrm{H} 1$ & $\mathrm{H} 2$ & $\mathrm{H} 3$ & H1 & $\mathrm{H} 2$ & $\mathrm{H} 3$ & $\mathrm{H} 1$ & $\mathrm{H} 2$ & $\mathrm{H} 3$ \\
\hline $10-\mathrm{Se}^{\mathrm{IV}}$ & 0.136 & $<$ LOD & $<$ LOD & $\begin{array}{l}6.37 \\
(36.3)\end{array}$ & $\begin{array}{l}4.15 \\
(58.5)\end{array}$ & $\begin{array}{l}1.81 \\
(81.9)\end{array}$ & 3.49 & 5.85 & 8.19 \\
\hline $10-\mathrm{Se}^{\mathrm{VI}}$ & 0.334 & $<$ LOD & $<$ LOD & $\begin{array}{l}5.82 \\
(41.8)\end{array}$ & $\begin{array}{l}4.29 \\
(57.1)\end{array}$ & $\begin{array}{l}3.14 \\
(68.6)\end{array}$ & 3.85 & 5.71 & 6.86 \\
\hline $20-\mathrm{Se}^{\mathrm{IV}}$ & 0.287 & $<$ LOD & $<$ LOD & $\begin{array}{l}13.9 \\
(30.5)\end{array}$ & $\begin{array}{l}9.75 \\
(51.3)\end{array}$ & $\begin{array}{l}8.02 \\
(59.9)\end{array}$ & 5.80 & 10.2 & 12.0 \\
\hline $20-\mathrm{Se}^{\mathrm{VI}}$ & 0.864 & $<\mathrm{LOD}$ & $<\mathrm{LOD}$ & $\begin{array}{l}12.4 \\
(38.0)\end{array}$ & $\begin{array}{l}7.61 \\
(62.0)\end{array}$ & $\begin{array}{l}5.17 \\
(75.2)\end{array}$ & 6.74 & 12.4 & 14.8 \\
\hline
\end{tabular}

${ }^{\mathrm{a}}$ The numbers $\left(10\right.$ and $\left.20 \mathrm{~g} \mathrm{ha}^{-1}\right)$ before the treatment type represent the level of ${ }^{77} \mathrm{Se}_{\mathrm{Fert}}$ application
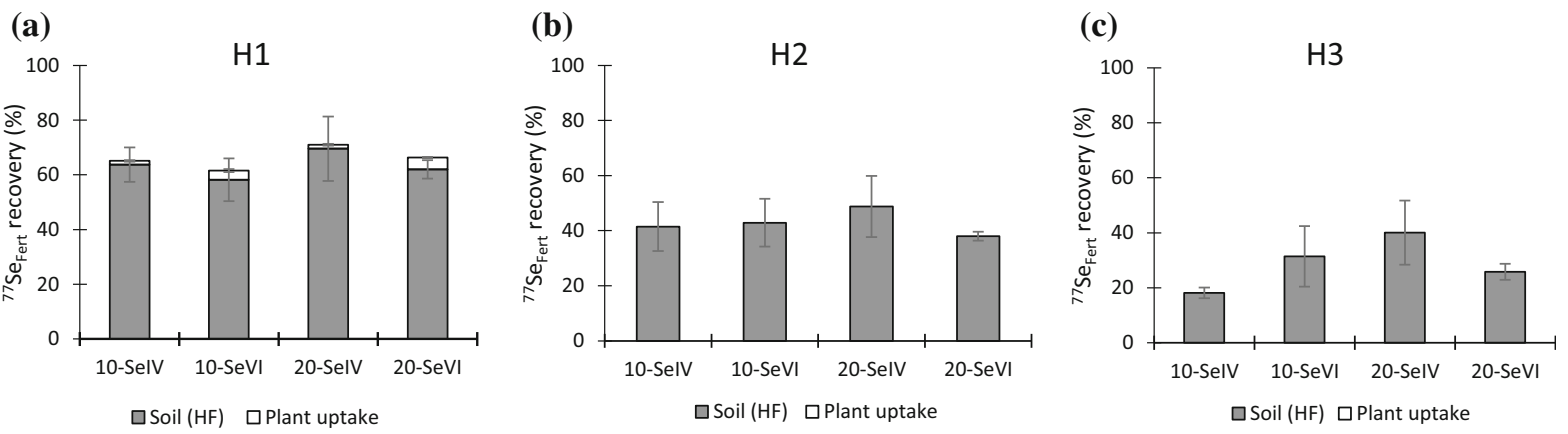

Fig. 1 Fate of ${ }^{77} \mathrm{Se}_{\mathrm{Fert}}$ in soil after a first wheat harvest (H1), b maize harvest (H2), and c second wheat harvest (H3). Error bars represent standard error of means $(n=4)$

soluble and adsorbed fractions in most of the samples was $\mathrm{Se}^{\mathrm{IV}}$ (supplementary material Table B1). It is reported that approximately $20 \%$ of the $\mathrm{Se}^{\mathrm{VI}}$ applied to Finnish soils is taken up by plants, whereas the remaining Se is reduced to $\mathrm{Se}^{\mathrm{IV}}$ and immobilised in the soil (Keskinen et al. 2009). The findings of this study are also consistent with Stroud et al. (2010) who studied the fate of $\mathrm{Se}$ added as $\mathrm{Se}^{\mathrm{VI}}$ to soils in the UK and reported that $\mathrm{Se}^{\mathrm{VI}}$ was not detectable in soil samples either before or after fertiliser application. It was initially thought that the calcareous nature of the soil might ensure the survival of some of the ${ }^{77} \mathrm{Se}_{\mathrm{Fert}}$ as $\mathrm{Se}^{\mathrm{VI}}$, at least at $\mathrm{H} 1$, but this was not the case.

The added ${ }^{77} \mathrm{Se}_{\text {Fert }}$ did not significantly increase total soil Se because the addition of 10 and $20 \mathrm{~g} \mathrm{ha}^{-1}$ would only contribute concentrations of 4 and $8 \mu \mathrm{g} \mathrm{kg}^{-1}$, respectively, assuming $2500 \mathrm{t} \mathrm{ha}^{-1}$ of topsoil. By contrast, the average concentration of the native soil Se was $139 \pm 9.12 \mu \mathrm{g} \mathrm{kg}^{-1}$.

Fractionation of selenium

Native soil Se $\left(\mathrm{Se}_{\mathrm{Nat}}\right)$

The three-step extraction procedure demonstrated that the fractionation of $\mathrm{Se}_{\mathrm{Nat}}$ was fairly consistent across all four sampling events ( $\mathrm{H} 0, \mathrm{H} 1, \mathrm{H} 2$, and $\mathrm{H} 3$ ) (supplementary material Fig. A2 and Table B2). The soluble and adsorbed fractions of $\mathrm{Se}_{\mathrm{Nat}}$ accounted for $<2.5 \% \quad\left(0.30-3.27 \mu \mathrm{g} \mathrm{kg}^{-1}\right) \quad$ and $<2 \%$ (1.12-2.61 $\left.\mathrm{g} \mathrm{kg}^{-1}\right)$, respectively, across all samples. The organically bound $\mathrm{Se}\left(\mathrm{Se}_{\mathrm{TMAH}}\right)$ was typically constant at $60 \%\left(75-88 \mu \mathrm{g} \mathrm{kg}^{-1}\right)$ for $\mathrm{Se}_{\mathrm{Nat}}$ in $\mathrm{H} 0, \mathrm{H} 1$, and $\mathrm{H} 2$ samples but was substantially reduced to $43 \%$ $\left(60 \mu \mathrm{g} \mathrm{kg}^{-1}\right)$ in $\mathrm{H} 3$ samples. The remaining $\mathrm{Se}_{\mathrm{Nat}}$ of 
40-57\% (47.4-78.2 $\left.\mathrm{\mu g} \mathrm{kg}^{-1}\right)$ may be regarded as a 'recalcitrant' fraction of Se, locked up within mineral structures (Keskinen et al. 2009; Mathers et al. 2015). Possible chemical forms of recalcitrant Se are not known. It is likely that a proportion of Se added to the soil from rock weathering, atmospheric deposition, or irrigation water could be converted to a recalcitrant phase within $\mathrm{CaCO}_{3}$; alternatively, it could simply represent Se within parent material, again possibly $\mathrm{CaCO}_{3}$, which slowly contributes more reactive fractions of Se due to weathering. Therefore, it is not clear whether the recalcitrant Se represents a sink or a source of bioavailable Se.

\section{Fertiliser Se $\left({ }^{77} \mathrm{Se}_{\mathrm{Fert}}\right)$}

The soluble and adsorbed fractions of ${ }^{77} \mathrm{Se}_{\mathrm{Fert}}$ in postH1 soils accounted for $8.5-8.6 \%$ (0.498$\left.0.545 \mathrm{~g} \mathrm{ha}^{-1}\right)$ and 5.3-6.3\% (0.340-0.365 $\left.\mathrm{g} \mathrm{ha}^{-1}\right)$, respectively, in $10 \mathrm{~g} \mathrm{ha}^{-1}$ application treatments, whereas for $20 \mathrm{~g} \mathrm{ha}^{-1}$ applications the soluble and adsorbed fractions accounted for 7.3-7.9\% $\left(0.978-1.020 \mathrm{~g} \mathrm{ha}^{-1}\right)$ and 4.0-6.1\% (0.501-0.849 g $\mathrm{ha}^{-1}$ ), respectively (supplementary material Fig. A3 and Table B3). There was no significant difference in the soluble fractions $\left(\mathrm{Se}_{\mathrm{sol}}\right.$ ) of $\mathrm{Se}^{\mathrm{IV}}$ and $\mathrm{Se}^{\mathrm{VI}}$ treatments and the same was observed for the adsorbed fraction $\left(\mathrm{Se}_{\mathrm{ads}}\right)$ (ANOVA, $p>0.05$ ). The average combined concentrations of soluble and adsorbed fractions for 10 and $20 \mathrm{~g} \mathrm{ha}^{-1}$ treatments varied with time and decreased to $4.54 \%\left(0.297 \pm 0.15 \mathrm{~g} \mathrm{ha}^{-1}\right)$ and $3.03 \%\left(0.201 \pm 0.11 \mathrm{~g} \mathrm{ha}^{-1}\right)$ in $\mathrm{H} 2$ soils but slightly increased to $9.80 \%\left(0.369 \pm 0.266 \mathrm{~g} \mathrm{ha}^{-1}\right)$ and $6.26 \%\left(0.254 \pm 0.173 \mathrm{~g} \mathrm{ha}^{-1}\right)$ in $\mathrm{H} 3$ soils. As found for $\mathrm{H} 1$ soils, there was no significant difference in the native soil soluble or adsorbed fractions of $\mathrm{Se}^{\mathrm{IV}}$ and $\mathrm{Se}^{\mathrm{VI}}$ treatments in $\mathrm{H} 2$ and $\mathrm{H} 3$ soils, respectively (ANOVA, $p>0.05$ ).

The results of sequential extraction for ${ }^{77} \mathrm{Se}_{\mathrm{Fert}}$ and $\mathrm{Se}_{\mathrm{Nat}}$ demonstrated that a comparatively larger proportion of freshly added Se was present in the bioavailable (soluble and adsorbed) fraction at $\mathrm{H} 1$ compared to $\mathrm{H} 2$ and $\mathrm{H} 3$ soils. However, available ${ }^{77} \mathrm{Se}_{\mathrm{Fert}}$ was too low to contribute to plant Se uptake in $\mathrm{H} 2$ and $\mathrm{H} 3$ crops which is consistent with the findings of Gissel-Nielsen et al. (1984) who found a minimal residual availability of $\mathrm{Se}$ in pasture systems. Similarly, Chilimba et al. (2012b) and Mathers et al. (2017) reported minimal recovery of residual Se in maize and wheat crops, respectively. Ligowe et al. (2019, 2020b) also reported much lower recoveries of residual Se in maize and green vegetables.

The remaining ${ }^{77} \mathrm{Se}_{\mathrm{Fert}}$ in $\mathrm{H} 1, \mathrm{H} 2$, and $\mathrm{H} 3$ soil samples was all present in an organically bound form; all the remaining ${ }^{77} \mathrm{Se}_{\mathrm{Fert}}$ was extractable with TMAH, and so there were insignificant concentrations present in a 'recalcitrant' pool. The sum of all extractable fractions (soluble, adsorbed, and organically bound) in each sample was equal to the total concentration of $\mathrm{Se}_{\mathrm{Fert}}$ in the soil after each harvest, but the total concentration decreased with time compared to the original application. An average decrease of $37 \%$ was observed in ${ }^{77} \mathrm{Se}_{\mathrm{Fert}}$ concentration after 72 days (H1) since the initial application; the remaining ${ }^{77} \mathrm{Se}_{\mathrm{Fer}}$ decreased further to $43 \%$ and $29 \%$ after 224 days (H2) and 439 days (H3), respectively.

Figure 2 shows the measured soil Se concentrations and modelled data (calculated from Eq. 1). The trend approached a nonzero asymptote within the time frame of the study, suggesting long-term retention of some of the ${ }^{77} \mathrm{Se}_{\mathrm{Fert}}$. However, as already discussed, the remaining ${ }^{77} \mathrm{Se}_{\text {Fert }}$ was virtually all present as humus-bound residues (extractable with TMAH) and was not available for plant uptake beyond H1. With limited data (four time points), the trends shown must be interpreted with caution. Application of $20 \mathrm{~g} \mathrm{ha}^{-1}$ showed the clearest contrast in $\mathrm{Se}_{\mathrm{Eq}}$ (Eq. 1) between $\mathrm{Se}^{\mathrm{IV}}$ and $\mathrm{Se}^{\mathrm{VI}}$ with $40 \%$ and $26 \%$ remaining in the soil;

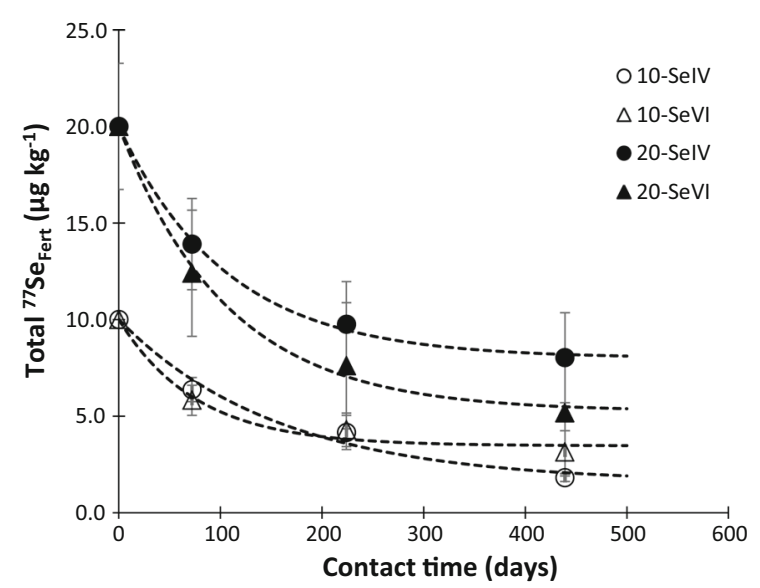

Fig. 2 Measured (data points) and modelled (dotted lines) concentration of ${ }^{77} \mathrm{Se}_{\mathrm{Fert}}$ in soil as a function of its residence time using a reversible first-order kinetics model. The numbers (10 and 20) before Se species $\left(\mathrm{Se}^{\mathrm{IV}}\right.$ and $\mathrm{Se}^{\mathrm{VI}}$ ) in the legend represent the application rate in $\mathrm{g} \mathrm{ha}^{-1}$. Error bars represent standard error of means $(n=4)$ 
equivalent values for $10 \mathrm{~g} \mathrm{ha}^{-1}$ applications were $16 \%$ and $35 \%$, but the overall trends were very similar over the 439-day period.

\section{Risk assessment of water contamination}

The continued loss of ${ }^{77} \mathrm{Se}_{\mathrm{Fert}}$ from soil to groundwater poses a potential risk of contamination to drinking water in the catchment area. Therefore, a simple risk assessment was undertaken to estimate the loss of $\mathrm{Se}$ to groundwater by considering the use of 6 million $\mathrm{L}$ $\mathrm{ha}^{-1}$ irrigation water applied as 12 irrigation events (50 $\mathrm{mm}$ depth). This is a common practice in the area due to the coarse-textured soil (Mountain Agriculture Research Centre, personal communication, August 2019). Approximately 30\% ( 3 and $6 \mathrm{~g} \mathrm{ha}^{-1}$ ) of ${ }^{77} \mathrm{Se}_{\mathrm{Fert}}$ was lost at $\mathrm{H} 1$ for the application rates of $10 \mathrm{~g} \mathrm{ha}^{-1}$ and $20 \mathrm{~g} \mathrm{ha}^{-1}$ which could therefore result in concentrations of $0.50 \mu \mathrm{g} \mathrm{L}^{-1}$ and $1.0 \mu \mathrm{g} \mathrm{L}^{-1} \mathrm{Se}$ in drainage water, respectively, after the wheat-growing season. Alternatively, in a worst-case scenario, if it is assumed that all the ${ }^{77} \mathrm{Se}_{\mathrm{Fert}}$ applied $(10$ and $20 \mathrm{~g} \mathrm{ha}^{-1}$ ) to the wheat crop was lost with the first irrigation of 0.5 million $\mathrm{L} \mathrm{ha}^{-1}$, this would result in 20 and $40 \mu \mathrm{g} \mathrm{L}^{-1}$ of Se in drainage water. Both of the above values, 20 and $40 \mu \mathrm{g} \mathrm{L}^{-1}$, are still below the US EPA maximum contamination level of $50 \mu \mathrm{g} \mathrm{L}^{-1}$ for Se in drinking water, and neither of these scenarios allows for the dilution of drainage water that would occur following egress of Se-enriched water from the soil into surface water systems.

\section{Distribution coefficient of $S e_{\text {Nat }}$ and ${ }^{77} \mathrm{Se}_{\mathrm{Fert}}$ in soil}

The $k d$ values for $\mathrm{Se}_{\mathrm{Nat}}$ and ${ }^{77} \mathrm{Se}_{\mathrm{Fert}}$ were very low with similar mean values of $0.76 \pm 0.141$ and $0.70 \pm 0.199$ demonstrating a very low absorption capacity in this soil to retain $\mathrm{Se}$ in an adsorbed reactive form. This is expected because the soil has a coarse texture, high $\mathrm{pH}$, and low organic carbon content. The lack of a significant difference in the $\mathrm{kd}$ values for $\mathrm{Se}_{\mathrm{Nat}}$ and ${ }^{77} \mathrm{Se}_{\mathrm{Fert}}$ (ANOVA, $p>0.05$ ) suggests that the added ${ }^{77} \mathrm{Se}$ has achieved isotopic equilibrium within the 'reactive' Se fractions $\left(\mathrm{Se}_{\mathrm{sol}}\right.$ and $\left.\mathrm{Se}_{\mathrm{ads}}\right)$. When Se is added to soil, some proportion of it will gradually transform into organically bound or recalcitrant phases, but the reactive pools should reach equilibrium rapidly. The low $k d$ values and low retention ability of this soil also confirm the necessity for repeated seasonal applications of Se to each crop.

Selenium in the wheat crop at Harvest 1 (H1)

The application of different levels and species of Se had no effect on crop yield which is consistent with other investigations (Curtin et al. 2008; Broadley et al. 2010; Mathers et al. 2017). The average yields of straw + chaff and grain, based on harvest of the central $1 \mathrm{~m}^{2}$ of each plot, were 4.8 and $3.5 \mathrm{t} \mathrm{ha}^{-1}$, respectively.

The concentrations of $\mathrm{Se}_{\mathrm{Nat}}$ in the aboveground biomass (sum of straw, chaff, and grain) were very small compared to ${ }^{77} \mathrm{Se}_{\mathrm{Fert}}$ and similar across all plots (Table 2). The concentration of $\mathrm{Se}_{\mathrm{Nat}}$ varied between plant tissues (straw, chaff, and grain) in all treatments (Fig. 3). Chaff had the highest average concentration of $\mathrm{Se}_{\mathrm{Nat}}$ at $7.15 \mu \mathrm{g} \mathrm{kg}^{-1}$ followed by straw $\left(2.87 \mu \mathrm{g} \mathrm{kg}^{-1}\right)$ and grain $\left(1.14 \mu \mathrm{g} \mathrm{kg}^{-1}\right)$ in all cases. The native Se concentration in chaff and grain was constant across all treatments. However, the concentration of $\mathrm{Se}_{\mathrm{Nat}}$ in straw revealed significant variation between different treatments (ANOVA, $p<0.05$ ) (Fig. 3); the reason for this is not clear as there is no reason to expect a difference in $\mathrm{Se}_{\mathrm{Nat}}$ in different plant tissues caused by the ${ }^{77} \mathrm{Se}_{\mathrm{Fert}}$ application. Furthermore, similar investigations (Chilimba et al. 2012a, b; Mathers et al. 2017; Ligowe et al. 2020b) in other type of soil have not shown changes in $\mathrm{Se}_{\mathrm{Nat}}$ concentration in plant tissues across different treatments. However, with $\mathrm{Se}_{\mathrm{Nat}}$ concentration being so small in all plant tissues it is possible that they may be subject to relatively substantial systematic analytical errors.

The concentration of Se was significantly greater in all plant tissues due to fertiliser Se application (Fig. 3). Both species of ${ }^{77} \mathrm{Se}_{\text {Fert }}\left(\mathrm{Se}^{\mathrm{IV}}\right.$ Fert and $\mathrm{Se}^{\mathrm{VI}}$ Fert $)$ enhanced Se concentration in the wheat plant (grain, chaff, and straw) at harvest, but ${ }^{77} \mathrm{Se}^{\mathrm{VI}}$ Fert was more effective compared to ${ }^{77} \mathrm{Se}^{\mathrm{IV}}$ Fert. A single application of 10 and $20 \mathrm{~g} \mathrm{ha}^{-1}$ of ${ }^{77} \mathrm{Se}^{\mathrm{IV}}{ }_{\text {Fert }}$ resulted in a 14- and 32-fold increase in grain Se compared to an extremely low grain Se concentration of $1.42 \mu \mathrm{g} \mathrm{kg}^{-1}$ in control plots. The same application rates of ${ }^{77} \mathrm{Se}^{\mathrm{VI}}$ Fert produced a 35- and 95-fold increase in grain $\mathrm{Se}$ over control plots.

The greater efficiency of $\mathrm{Se}^{\mathrm{VI}}$ in enhancing plant Se content observed in this study is consistent with other investigations, notwithstanding the calcareous nature 
Table 2 Concentration of Se in wheat (sum of chaff, grain, and straw accounting for their relative masses per unit area) at $\mathrm{H} 1$ originating from soil $\left(\mathrm{Se}_{\mathrm{Nat}}\right)$ and fertiliser $\left({ }^{77} \mathrm{Se}_{\mathrm{Fert}}\right)$, and a plant

\begin{tabular}{|c|c|c|c|c|}
\hline Treatments & $\begin{array}{l}\text { Plant total Se } \\
\left(\mu \mathrm{g} \mathrm{kg}^{-1}\right)\end{array}$ & $\begin{array}{l}\text { Soil derived } \mathrm{Se}\left(\mathrm{Se}_{\mathrm{Nat}}\right) \\
\left(\mu \mathrm{g} \mathrm{kg}^{-1}\right)\end{array}$ & $\begin{array}{l}\text { Fertiliser-derived Se }\left({ }^{77} \mathrm{Se}_{\text {Fert }}\right) \\
\left(\mu \mathrm{kg}^{-1}\right)\end{array}$ & Plant enrichment factor \\
\hline Control & 2.95 & 2.76 & 0.188 & \\
\hline $10-\mathrm{Se}^{\mathrm{IV}}$ & 17.7 & 3.25 & 14.5 & 6.02 \\
\hline $10-\mathrm{Se}^{\mathrm{VI}}$ & 43.9 & 3.56 & 40.3 & 14.9 \\
\hline $20-\mathrm{Se}^{\mathrm{IV}}$ & 38.0 & 3.26 & 34.7 & 12.9 \\
\hline $20-\mathrm{Se}^{\mathrm{VI}}$ & 116 & 2.94 & 113 & 39.5 \\
\hline
\end{tabular}

The numbers in 'Treatments' before Se species (selenite $\left(\mathrm{Se}^{\mathrm{IV}}\right)$ and selenate $\left(\mathrm{Se}^{\mathrm{VI}}\right)$ ) indicate the Se application rate $(10$ and $\left.20 \mathrm{~g} \mathrm{ha}^{-1}\right)$

(a)

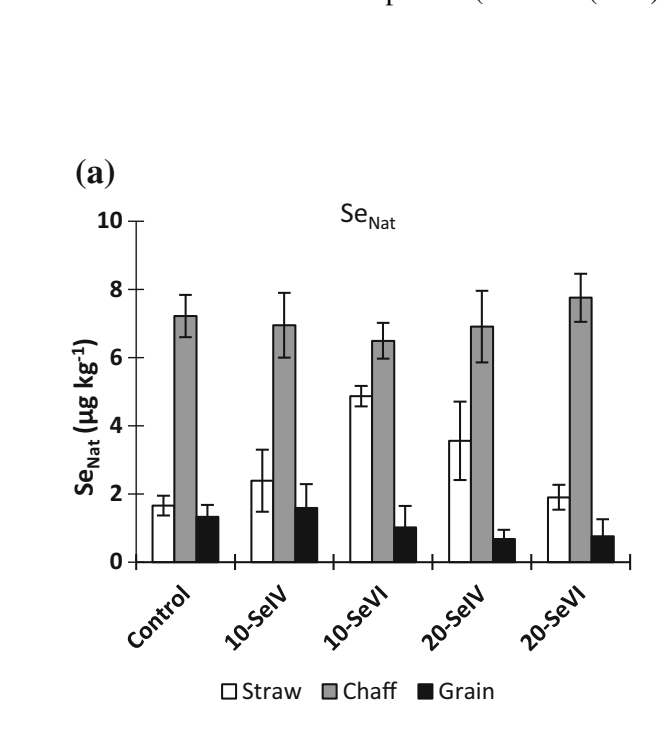

enrichment factor (the proportional increase in Se in the plant above native levels originating from the application of ${ }^{77} \mathrm{Se}_{\mathrm{Fert}}$ ) g $\left.\mathrm{a}^{-1}\right)$

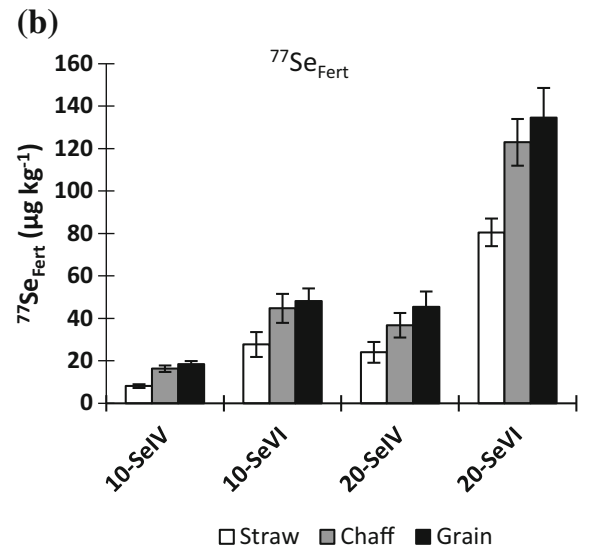

Fig. 3 Selenium concentration in plant tissues at Harvest $1(\mathrm{H} 1)$ originating from a soil native $\mathrm{Se}\left(\mathrm{Se} \mathrm{Nat}_{\mathrm{N}}\right)$ and $\mathbf{b}$ fertiliser-derived $\mathrm{Se}$ $\left({ }^{77} \mathrm{Se}_{\mathrm{Fert}}\right)$. Error bars represent standard error of means $(n=4)$. Note the different scales in Fig. $4 \mathrm{a}, \mathrm{b}$

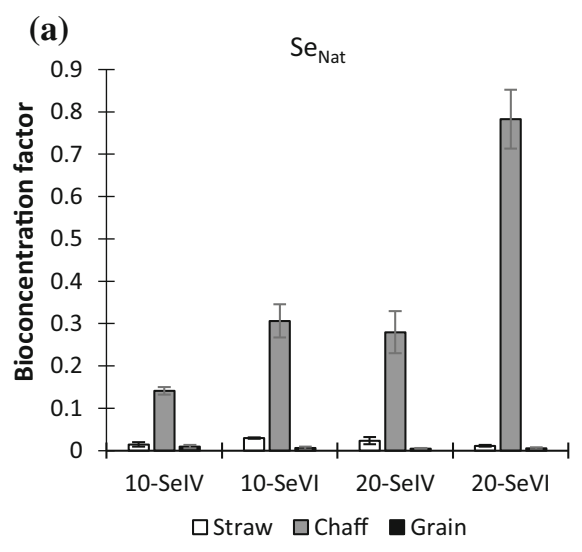

Fig. 4 Bioconcentration factor (Eq. 3) for native $\mathrm{Se}\left(\mathrm{Se}_{\mathrm{Nat}}\right)$ and fertiliser-derived $\mathrm{Se}\left({ }^{77} \mathrm{Se}_{\mathrm{Fert}}\right)$ in different parts of wheat plants. Error bars represent standard error of means $(n=4)$. Note the

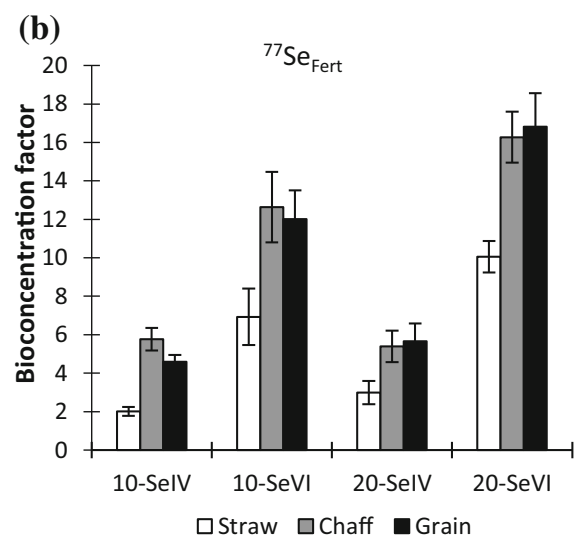

different scales in a, b. The numbers (10 and 20) before the Se species symbol represent the amount of Se applied in $\mathrm{g} \mathrm{ha}^{-1}$ 
Table 3 Recovery (\% of application) of ${ }^{77} \mathrm{Se}_{\mathrm{Fert}}$ in different plant tissues at the first wheat harvest (H1). Treatments below indicate the Se application rate $\left(10\right.$ and $\left.20 \mathrm{~g} \mathrm{ha}^{-1}\right)$ and the $\mathrm{Se}$ species $\left(\right.$ selenite $\left(\mathrm{Se}^{\mathrm{IV}}\right)$ and selenate $\left(\mathrm{Se}^{\mathrm{VI}}\right)$ )

\begin{tabular}{|c|c|c|c|c|}
\hline \multirow[t]{2}{*}{ Plant tissue } & \multicolumn{4}{|c|}{${ }^{77} \mathrm{Se}_{\mathrm{Fert}}$ recovery in wheat crop (\% of application) } \\
\hline & $10-\mathrm{Se}^{\mathrm{IV}}$ & $10-\mathrm{Se}^{\mathrm{VI}}$ & $20-\mathrm{Se}^{\mathrm{IV}}$ & $20-\mathrm{Se}^{\mathrm{VI}}$ \\
\hline Straw & 0.250 & 0.797 & 0.393 & 1.05 \\
\hline Chaff & 0.345 & 0.821 & 0.353 & 1.17 \\
\hline Grain & 0.768 & 1.72 & 0.686 & 2.10 \\
\hline Total plant ${ }^{\mathrm{a}}$ & 1.36 & 3.34 & 1.43 & 4.32 \\
\hline
\end{tabular}

a'Total plant' represents the sum of straw, chaff, and grain; roots were not sampled

of the soils in Gilgit-Baltistan. Gupta and Winter (1989) reported that $\mathrm{Se}^{\mathrm{VI}}$ applications resulted in 5-18 times greater Se concentrations in forages and barley grain compared to the same application of $\mathrm{Se}^{\mathrm{IV}}$. Chen et al. (2002) reported a ninefold increase in rice Se in China, compared to a 6.6-fold increase, as a result of $20 \mathrm{~g} \mathrm{ha}^{-1}$ application of $\mathrm{Se}^{\mathrm{VI}}$ and $\mathrm{Se}^{\mathrm{IV}}$, respectively. Boldrin et al. (2013) applied $\mathrm{Se}^{\mathrm{IV}}$ and $\mathrm{Se}^{\mathrm{VI}}$ to soil, as a foliar spray, and found that $\mathrm{Se}^{\mathrm{VI}}$ was more effective in raising rice $\mathrm{Se}$ concentrations in Brazil for both methods of application. Ros et al. (2016) compared a large set of data on Se biofortification and found that, on average, $\mathrm{Se}^{\mathrm{VI}}$ was 33 times more effective in increasing plant Se contents compared to $\mathrm{Se}^{\mathrm{IV}}$ at the same rate of application. However, in the current trial, for each $\mathrm{g} \mathrm{ha}^{-1}$ of $\mathrm{Se}^{\mathrm{VI}}$ applied the grain Se concentration was increased by only $4.76-6.70 \mu \mathrm{g} \mathrm{kg}^{-1}$, which is less efficient compared to other investigations. Broadley et al. (2010), Chilimba et al. (2012a), and Mathers et al. (2017), respectively, reported increases in grain Se concentration of $16-26 \mu \mathrm{g} \mathrm{kg}^{-1}$, $15-21 \mu \mathrm{g} \mathrm{kg}^{-1}$, and $12.1-17.3 \mu \mathrm{g} \mathrm{kg}^{-1}$ for each $\mathrm{g} \mathrm{ha}^{-1}$ of $\mathrm{Se}^{\mathrm{VI}}$ applied.

\section{Recovery of ${ }^{77} e_{\text {Fert }}$ species in plants at $\mathrm{HI}$}

The recovery of ${ }^{77} \mathrm{Se}_{\mathrm{Fert}}$ by wheat plants (sum of straw, chaff, and grain) from soil was different for the two Se species (Table 3): selenate recovery was 33-40\% greater than that of $\mathrm{Se}^{\mathrm{IV}}$ Fert at application rates of both 10 and $20 \mathrm{~g} \mathrm{ha}^{-1}$. The average recoveries of $\mathrm{Se}^{\mathrm{IV}}$ Fert by wheat plants were only $1.36 \%$ and $1.43 \%$ for 10 and $20 \mathrm{~g} \mathrm{ha}^{-1}$ application, respectively (Table 3); the equivalent recoveries for $\mathrm{Se}^{\mathrm{VI}}$ Fert were $3.34 \%$ and $4.32 \%$, respectively. For both species, the recovery was greater at the higher application rate $\left(20 \mathrm{~g} \mathrm{ha}^{-1}\right)$.
The recovery of ${ }^{77} \mathrm{Se}_{\mathrm{Fert}}$ species also varied between plant tissues (Table 3); grain had a higher recovery in all cases followed by chaff and straw.

Compared to other investigations on field-grown wheat and other cereal crops, the recovery of both species was low. Mathers et al. (2017) reported $25.9-44.5 \%$ recovery in wheat plants grown on three contrasting sites in the UK with an application of $10 \mathrm{~g} \mathrm{ha}^{-1}$ of ${ }^{77} \mathrm{Se}^{\mathrm{VI}}$. Broadley et al. (2010) observed recoveries of $19.6-34.7 \%$ in a wheat crop (grain + straw) following $\mathrm{Se}^{\mathrm{VI}}$ (aqueous $\mathrm{Na}_{2} \mathrm{SeO}_{4}$ ) application at six different rates (ranging from 5 to $100 \mathrm{~g} \mathrm{ha}^{-1}$ ) in the UK. However, Lyons et al. (2004) reported slightly smaller recoveries of $1.8-9.3 \%$ for foliar application of $\mathrm{Se}^{\mathrm{VI}}$ at four different rates $(10,30,100$, and $300 \mathrm{~g} \mathrm{ha}^{-1}$ ) to a wheat crop in Australia. Similarly, Ducsay and Ložek (2006) reported plant uptake of 2.4-9.3\% for foliar application of Se to a wheat crop in Slovakia.

The recovery of ${ }^{77} \mathrm{Se}_{\mathrm{Fert}}$ in wheat grain (first crop) observed for different treatments (Table 3) was smaller than values reported for wheat in the literature: 12.4-15.2\% (Mathers et al. 2017), 10-17.3\% (Broadley et al. 2010), 12.7-17\% (Curtin et al. 2008), 6.5\% (Lyons et al. 2004), and 2-6\% (Stephen et al. 1989). Recovery was also less than the $6.5-10.8 \%$ values reported by Chilimba et al. (2012a) for a maize crop.

The low ${ }^{77} \mathrm{Se}_{\mathrm{Fer}}$ recoveries in this study compared to other investigations conducted elsewhere could be due to low crop yield, soil characteristics, and possibly a limited period of ${ }^{77} \mathrm{Se}_{\mathrm{Fert}}$ availability for plant uptake in the Gilgit-Baltistan soils. Soil texture was sandy with low $\mathrm{CaCO}_{3}$ and organic carbon contents, which may reduce nutrient retention and thereby render the ${ }^{77} \mathrm{Se}_{\mathrm{Fert}}$ more prone to leaching after irrigation. 
Table 4 Bioavailability ratio $\left(B_{\mathrm{R}}\right.$; Eq. 4$)$ in plant tissues of the $\mathrm{H} 1$ wheat crop for different concentrations of fertiliser-derived selenite $\left(\mathrm{Se}^{\mathrm{IV}}\right)$ and selenate $\left(\mathrm{Se}^{\mathrm{VI}}\right)$

\begin{tabular}{lllll}
\hline Plant tissue & \multicolumn{4}{l}{ Bioavailability ratio $\left(B_{\mathrm{R}}\right)$ of ${ }^{77} \mathrm{Se}_{\mathrm{Fert}}: \mathrm{Se}_{\mathrm{Nat}}$} \\
\cline { 2 - 5 } & $10-\mathrm{Se}^{\mathrm{IV}}$ & $10-\mathrm{Se}^{\mathrm{VI}}$ & $20-\mathrm{Se}^{\mathrm{IV}}$ & $20-\mathrm{Se}^{\mathrm{VI}}$ \\
\hline Straw & 69.4 & 91.8 & 72 & 376 \\
Chaff & 34.8 & 111 & 41.4 & 136 \\
Grain & 187 & 764 & 490 & 1261 \\
\hline
\end{tabular}

The $\mathrm{BR}$ is the ratio of $\mathrm{BCF}$ values for added $\mathrm{Se}\left({ }^{77} \mathrm{Se}_{\mathrm{Fert}}\right)$ to that of soil-derived $\mathrm{Se}\left(\mathrm{Se}_{\mathrm{Nat}}\right)$

*The number (10 and 20) before the Se species symbol represents the amount of Se applied in $\mathrm{g} \mathrm{ha}^{-1}$

\section{Bioconcentration factor of Se $e_{\text {Nat }}$ and ${ }^{77} \mathrm{Se}_{\mathrm{Fert}}$}

The values of $\mathrm{BCF}$ for ${ }^{77} \mathrm{Se}_{\mathrm{Fert}}\left(\mathrm{Se}^{\mathrm{IV}}\right.$ and $\left.\mathrm{Se}^{\mathrm{VI}}\right)$ were significantly larger than those of $\mathrm{Se}_{\mathrm{Nat}}$ (Fig. 4). This is consistent with findings from Mathers et al. (2017) who observed a higher BCF for wheat plants fertilised with $\mathrm{Se}^{\mathrm{VI}}$ compared to their control plots. Furthermore, as expected, the $\mathrm{BCF}$ of ${ }^{77} \mathrm{Se}^{\mathrm{VI}}$ Fert was greater than that of ${ }^{77} \mathrm{Se}^{\mathrm{IV}}$ Fert (Fig. 4) due to greater solubility (Peng et al. 2017). The other reason for differences in $\mathrm{BCF}$ between $\mathrm{Se}^{\mathrm{IV}}$ and $\mathrm{Se}^{\mathrm{VI}}$ may lie in the mechanisms governing root uptake from soil and subsequent translocation to aerial parts of the plant. Selenate is freely absorbed by plant roots via sulphate transporters and then transported through xylem vessels into plant stems and leaves, whereas a fraction of $\mathrm{Se}^{\mathrm{IV}}$ is likely to be converted to $\mathrm{Se}^{\mathrm{VI}}$ or organic $\mathrm{Se}$ before being transported to other parts of the plant (White 2016; Ali et al. 2017). The BCF also varied between different parts of the plant in the same treatment as the BCF values for ${ }^{77} \mathrm{Se}_{\mathrm{Fert}}$ in grain and chaff were similar but substantially greater than for straw due to different abilities of tissue in various parts of the plant to accumulate or retain Se. The other reason for the greater concentration of Se in grain is the transportation of Se in phloem from leaves to grains.

Differences in BCF between ${ }^{77} \mathrm{Se}_{\mathrm{Fert}}$ and $\mathrm{Se}_{\mathrm{Nat}}$ and between the applied ${ }^{77} \mathrm{Se}_{\mathrm{Fert}}$ species of $\mathrm{Se}^{\mathrm{IV}}$ and $\mathrm{Se}^{\mathrm{VI}}$ reflect differences in bioavailability. The average $B_{R}$ of $\mathrm{Se}_{\mathrm{Fert}} / \mathrm{Se}_{\mathrm{Nat}}$ for the H1 wheat crop confirmed the large difference in bioavailability of ${ }^{77} \mathrm{Se}_{\mathrm{Fert}}$ compared to $\mathrm{Se}_{\mathrm{Nat}}$ to all tissues of the wheat (Table 4); in particular, the bioavailability of ${ }^{77} \mathrm{Se}^{\mathrm{VI}}$ Fert to wheat grain was 764 and 1261 times that of $\mathrm{Se}_{\mathrm{Nat}}$ at applications of 10 and $20 \mathrm{~g} \mathrm{ha}^{-1}$, respectively. The $B_{\mathrm{R}}$ values of ${ }^{77} \mathrm{Se}_{\mathrm{Fert}} / \mathrm{Se}_{\mathrm{Nat}}$ were comparable with other Se biofortification investigations (Stroud et al. 2010b; Chilimba et al. 2012a; Galinha et al. 2012) as cited in Mathers et al. (2017) and confirmed the greater bioavailability of ${ }^{77} \mathrm{Se}_{\mathrm{Fert}}{ }_{\mathrm{VI}}$ (Table 4). Ali et al. (2017) studied the bioavailability of $\mathrm{Se}^{\mathrm{IV}}$ and $\mathrm{Se}^{\mathrm{VI}}$ to wheat plant in a pot experiment and found that mobility and availability of $\mathrm{Se}^{\mathrm{VI}}$ for plant uptake was 40-90\% higher than that of $\mathrm{Se}^{\mathrm{IV}}$. Similarly, Fan et al. (2015) from his studies on transformation and bioavailability of $\mathrm{Se}\left(\mathrm{Se}^{\mathrm{IV}}\right.$ and $\left.\mathrm{Se}^{\mathrm{VI}}\right)$ applied to tobacco plants reported that $\mathrm{Se}^{\mathrm{VI}}$ was 4.3-7.9 times more bioavailable than $\mathrm{Se}^{\mathrm{IV}}$.

Values of $B_{R}$ varied between different parts of the plant (Table 4) and were greater in grain than in chaff and straw (ANOVA, $p<0.001$ ); there was no significant difference between chaff and straw (ANOVA, $p>0.05$ ). Possible reasons for a greater $\mathrm{B}_{\mathrm{R}}$ in grain lie in the timing, mode of ${ }^{77} \mathrm{Se}_{\mathrm{Fert}}$ application, and species of ${ }^{77} \mathrm{Se}_{\text {Fert }}$. The ${ }^{77} \mathrm{Se}_{\text {Fert }}$ was applied at early stem extension stage, and its greater bioavailability compared to $\mathrm{Se}_{\mathrm{Nat}}$ would produce a greater concentration of ${ }^{77} \mathrm{Se}_{\mathrm{Fert}}$ in leaves which is then supplied to grain when its formation begins. The concentration of Se is generally greater in leaves before anthesis and then starts to decrease when its translocation from leaves to reproductive organs begins (White 2016). Furthermore, because ${ }^{77} \mathrm{Se}_{\mathrm{Fert}}$ was sprayed on the plant canopy it is likely that some of it may have been absorbed into leaves and translocated via phloem from leaves to grain. The $\mathrm{B}_{\mathrm{R}}$ values for $\mathrm{Se}^{\mathrm{VI}}$ were greater compared to $\mathrm{Se}^{\mathrm{IV}}$ because $\mathrm{Se}^{\mathrm{VI}}$ is readily translocated from roots to other parts of the plant, while $\mathrm{Se}^{\mathrm{IV}}$ tends to accumulate in roots ( $\mathrm{Li}$ et al. 2008).

\section{Consequences of biofortification for dietary Se intake}

Wheat is the most important staple crop in Pakistan (Raza 2018) and forms an essential component of the daily diet for the majority $(\sim 80 \%)$ of the local population (Zia et al. 2014). The average daily consumption of wheat-based food in Pakistan is $350 \mathrm{~g}$ person $^{-1}$ and accounts for $75 \%$ of the daily calorific intake for an individual (Zia et al. 2014). Considering the average daily wheat consumption, the Se concentration in wheat grown on the control plots of this experiment would provide only $0.5 \mu \mathrm{g}$ 
Table 5 Grain Se dietary intake resulting from different Se treatments, compared to reliance on native soil-derived Se

\begin{tabular}{|c|c|c|c|c|c|}
\hline \multirow[t]{2}{*}{ Treatments } & \multicolumn{2}{|c|}{$\begin{array}{l}\text { Se concentration in grain } \\
\left(\mu \mathrm{g} \mathrm{kg}^{-1}\right)\end{array}$} & \multicolumn{2}{|c|}{$\begin{array}{l}\text { Adult daily Se intake from grain } \\
\left(\mu \mathrm{g} \text { person }^{-1}\right)\end{array}$} & \multirow[t]{2}{*}{$\begin{array}{l}\text { Proportion }(\%) \text { of recommended } \\
\text { adult daily Se intake (RDI) }\end{array}$} \\
\hline & Mean & Standard error & Mean & Standard error & \\
\hline Controls & 1.42 & 0.260 & 0.497 & 0.090 & 0.904 \\
\hline $10-\mathrm{Se}^{\mathrm{IV}}$ & 20.0 & 1.86 & 7.00 & 0.650 & 12.7 \\
\hline $10-\mathrm{Se}^{\mathrm{VI}}$ & 49.0 & 6.58 & 17.2 & 2.30 & 31.2 \\
\hline $20-\mathrm{Se}^{\mathrm{IV}}$ & 46.0 & 7.54 & 16.1 & 2.64 & 29.3 \\
\hline $20-\mathrm{Se}^{\mathrm{VI}}$ & 135 & 14.2 & 47.4 & 4.97 & 86.2 \\
\hline
\end{tabular}

Treatments below indicate the Se application rate $\left(10\right.$ and $\left.20 \mathrm{~g} \mathrm{ha}^{-1}\right)$ and the Se species (selenite $\left(\mathrm{Se}^{\mathrm{IV}}\right)$ and $\left.\mathrm{Selenate}\left(\mathrm{Se}^{\mathrm{VI}}\right)\right)$

person $^{-1}$ day $^{-1}$ which accounts for $<1 \%$ of the WHO-recommended $\left(55-70 \mu \mathrm{g} \mathrm{day}^{-1}\right)$ daily $\mathrm{Se}$ intake (Table 5). However, the biofortified wheat grain produced in this study with the application of 10 and $20 \mathrm{~g} \mathrm{ha}^{-1}{ }^{77} \mathrm{Se}_{\mathrm{Fert}}{ }^{\mathrm{VI}}$ would provide 17.2 and $47.4 \mu \mathrm{g} \mathrm{day}^{-1}$ accounting for $31.2 \%$ and $86.2 \%$ of the daily requirement. By contrast, the application of ${ }^{77} \mathrm{Se}_{\mathrm{Fert}}{ }_{\mathrm{IV}}$ at the same level would provide only 7 and $16.1 \mu \mathrm{g}$ person $^{-1}$ day $^{-1}$ contributing $12.7 \%$ and $29.3 \%$ towards the recommended daily Se intake. Based on Se concentrations in a typical Pakistani food basket from values reported in the literature, the $\mathrm{Se}$ contribution from other sources is around $25 \mu \mathrm{g} \mathrm{day}^{-1}$ (Hussain 2001; Iqbal et al. 2008; USDA 2019). Therefore, the consumption of wheat flour obtained from 10 and $20 \mathrm{ha}^{-1} \mathrm{Se}^{\mathrm{VI}}$ application would increase Se intake to 42.2 and $72.4 \mu \mathrm{g} \mathrm{day}^{-1}$ person $^{-1}$ for individuals with access to diverse food sources, assuming that $25 \mu \mathrm{g} \mathrm{day}^{-1}$ has come from those other sources.

The results of this study suggest that wheat biofortification with just $20 \mathrm{~g} \mathrm{ha}^{-1}$ of $\mathrm{Se}^{\mathrm{VI}}$ would be a successful strategy for boosting daily per-capita $\mathrm{Se}$ intake into the range required to avoid Se deficiency. Chilimba et al. (2012a) estimated that the addition of $5 \mathrm{~g} \mathrm{ha}^{-1}$ of Se to Malawi soils represented a raw material cost of just 1.6-3.5 US cents ha ${ }^{-1}$ year $^{-1}$.

\section{Residual Se in the crop at $\mathrm{H} 2$ and $\mathrm{H} 3$}

No ${ }^{77} \mathrm{Se}_{\text {Fert }}$ could be detected in the first rotation crop (maize) at $\mathrm{H} 2$ or the second wheat crop at H3. Thus, within analytical error, all the Se measured in all parts of the maize (grain, husk, leaf, and stem) and wheat (straw, chaff, and grain) was soil-derived. This is consistent with the observation that the major proportion of ${ }^{77} \mathrm{Se}_{\mathrm{Fert}}$ remaining in the soil had become organically bound (TMAH-extractable) and was unavailable for plant uptake. The TMAH extraction follows extraction with phosphate which should have dissolved 'adsorbed' forms of Se. Whatever ${ }^{77} \mathrm{Se}_{\mathrm{Fert}}$ was still available in the soluble and adsorbed fractions was at too low a concentration to measurably contribute to plant uptake. The negligible recovery of residual $\mathrm{Se}$ in the following crops is consistent with other investigations. Mathers et al. (2017) observed a negligible amount of residual Se in follow-up crops in his experiment on ${ }^{77} \mathrm{Se}$ application to winter wheat at sites in the $\mathrm{UK}$ with $10 \mathrm{~g} \mathrm{ha}^{-1} \mathrm{Se}^{\mathrm{VI}}$ applications. Stroud et al. (2010b) reported that no significant difference was found in Se concentration of wheat grain from control plots compared to those that were previously treated with 10 or $20 \mathrm{~g} \mathrm{ha}^{-1}$ of $\mathrm{Se}$ as $\mathrm{Na}_{2} \mathrm{SeO}_{4}$. Similarly, Gupta et al. (1993) also reported no effect of residual Se on barley grain Se content in Canada with applications at three different rates (10, 20 , and $40 \mathrm{~g} \mathrm{ha}^{-1}$ ) of $\mathrm{Se}^{\mathrm{IV}}$ and $\mathrm{Se}^{\mathrm{VI}}$, respectively. Chilimba et al. (2012b) reported a very small recovery $(0.78 \%$ and $2 \%)$ of isotopically labelled residual ${ }^{74} \mathrm{Se}$ in maize grain at two different field sites in Malawi, treated with $10 \mathrm{~g} \mathrm{ha}^{-1}{ }^{74} \mathrm{Se}^{\mathrm{VI}}$ the previous year. In addition, Wang et al. (2017) also reported a $77.9 \%$ and $91.2 \%$ reduction in Se concentration in wheat and maize grain from plots, which were treated with 30 and $60 \mathrm{~g} \mathrm{ha}^{-1}$ of $\mathrm{Se}$ in previous cropping season in China. Almost all previous studies suggest that, regardless of soil type, virtually all applied Se retained by topsoil is rendered unavailable for uptake by the time of a second crop. 


\section{Conclusions}

Both species of ${ }^{77} \mathrm{Se}_{\mathrm{Fert}}\left(\mathrm{Se}^{\mathrm{IV}}\right.$ and $\left.\mathrm{Se}^{\mathrm{VI}}\right)$ at application rates of 10 and $20 \mathrm{~g} \mathrm{ha}^{-1}$ increased Se concentration in a wheat crop. However, $\mathrm{Se}^{\mathrm{VI}}$ was more efficient in increasing wheat grain Se at $\mathrm{H} 1$ and produced 33-40\% greater recovery compared to $\mathrm{Se}^{\mathrm{IV}}$. A single application of $20 \mathrm{~g} \mathrm{ha}^{-1} \mathrm{Se}^{\mathrm{VI}}$ increased Se concentration in wheat grain to $135 \mathrm{\mu g} \mathrm{kg}^{-1}$ compared to an extremely low Se concentration of $1.42 \mu \mathrm{g} \mathrm{kg}^{-1}$ from control plots. Considering an average per-capita wheat consumption of $350 \mathrm{~g} \mathrm{day}^{-1}$ in Pakistan, $20 \mathrm{~g} \mathrm{ha}^{-1} \mathrm{Se}^{\mathrm{VI}}$ would provide c. $47 \mu \mathrm{g}$ person ${ }^{-1}$ day $^{-1}$ of dietary Se, which would be enough to avoid Se deficiency in the Gilgit-Baltistan population. There was no ${ }^{77} \mathrm{Se}_{\text {Fert }}$ detected in subsequent harvests: $\mathrm{H} 2$ (maize) and $\mathrm{H} 3$ (wheat) crops suggesting continued annual applications of $\mathrm{Se}_{\mathrm{Fert}}$ would be required to sustain viable biofortification.

On average, $71.1 \pm 16.9 \%$ of ${ }^{77} \mathrm{Se}_{\mathrm{Fert}}$ was lost from the soil at the time of final soil sampling (H3-July 2019). There was no evidence of ${ }^{77} \mathrm{Se}_{\mathrm{Fert}}$ assimilation into a recalcitrant mineral phase within the timescale of the trial despite clear evidence of native recalcitrant Se. However, the ${ }^{77} \mathrm{Se}_{\text {Fert }}$ which remained in soil after every harvest was largely $(\geq 90 \%)$ present in an organically bound form (TMAH extractable) which rendered it completely unavailable for plant uptake so that ${ }^{77} \mathrm{Se}_{\text {Fert }}$ was not detected in $\mathrm{H} 2$ and $\mathrm{H} 3$ crops. Therefore, it is clear that Se application to crops in every growing season would be required to obtain an increased concentration of $\mathrm{Se}$ in crops. Further research is required to more fully assess (1) the effect of Se lost from the soil on water quality immediately following application and (first) irrigation and (2) any longer-term residual effects from repeated applications as the capacity of these soils to continue fixing $\mathrm{Se}$ into organic forms is unknown.

Acknowledgements Financial support for this study was provided by the University of Nottingham. MA and SA ran the field trial at the Mountain Agriculture Research Centre Gilgit station and collected all soil and plant samples. SA, SDY, and EHB analysed the samples. SA, SDY, EHB, and MJW analysed and processed the data. All authors were involved in writing and reviewing the manuscript. Thanks are extended to Professor Martin Broadley (University of Nottingham) for his invaluable comments on this manuscript.

Funding Financial support for this study was provided by the University of Nottingham.
Availability of data and materials The authors confirm that the summary of data supporting the findings of this study are available within the article. However, detailed data of this study are available from corresponding author upon request.

Code availability Not applicable.

\section{Compliance with ethical standards}

Conflict of interest The authors declare that they have no conflict of interest.

Open Access This article is licensed under a Creative Commons Attribution 4.0 International License, which permits use, sharing, adaptation, distribution and reproduction in any medium or format, as long as you give appropriate credit to the original author(s) and the source, provide a link to the Creative Commons licence, and indicate if changes were made. The images or other third party material in this article are included in the article's Creative Commons licence, unless indicated otherwise in a credit line to the material. If material is not included in the article's Creative Commons licence and your intended use is not permitted by statutory regulation or exceeds the permitted use, you will need to obtain permission directly from the copyright holder. To view a copy of this licence, visit http://creativecommons.org/licenses/by/4.0/.

\section{References}

Ahmad, S. (2020). Geochemical dynamics and bioavailability of iodine and selenium. Ph.d., thesis. University of Nottingham.

Alfthan, G., Eurola, M., Ekholm, P., Venäläinen, E., Root, T., Korkalainen, K., et al. (2015). Effects of nationwide addition of selenium to fertilisers on foods, and animal and human health in Finland: From deficiency to optimal selenium status of the population. Journal of Trace Elements in Medicine and Biology, 31, 142-147.

Ali, F., Peng, Q., Wang, D., Cui, Z., Huang, J., Fu, D., \& Liang, D. (2017). Effects of selenite and selenate application on distribution and transformation of selenium fractions in soil and its bioavailability for wheat (Triticum aestivum L.). Environtal Science and Pollution Research, 24, 8315-8325.

Antonyak, H., Iskra, R., Panas, N., \& Lysiuk, R. (2018). Selenium. In M. Malavolta \& E. Mocchegiani (Eds.), Trace elements and minerals in health and longevity (pp. 63-98). Dordrecht: Springer.

Boldrin, P. F., Faquin, V., Ramos, S. J., Boldrin, K. V. F., Ávila, F. W., \& Guilherme, L. R. G. (2013). Soil and foliar application of selenium in rice biofortification. Journal of Food Composition and Analysis, 31, 238-244.

Broadley, M. R., Alcock, J., Alford, J., Cartwright, P., Foot, I., Fairweather-Tait, S. J., et al. (2010). Selenium biofortification of high-yielding winter wheat (Triticum aestivum L.) by liquid or granular Se fertilisation. Plant and Soil, $332,5-18$. 
Broadley, M. R., White, P. J., Bryson, R. J., Meacham, M. C., Bowen, H. C., Johnson, S. E., et al. (2006). Biofortification of UK food crops with selenium. Proceedings of the Nutrition Society, 65, 169-181.

Brown, K. M., \& Arthur, J. R. (2001). Selenium, selenoproteins and human health: A review. Public Health Nutrition, 4, 593-599.

Chen, L., Yang, F., Xu, J., Hu, Y., Hu, Q., Zhang, Y., \& Pan, G. (2002). Determination of selenium concentration of rice in China and effect of fertilization of selenite and selenate on selenium content of rice. Journal of Agricultural and Food Chemistry, 50, 5128-5130.

Chilimba, A. D. C., Young, S. D., Black, C. R., Meacham, M. C., Lammel, J., \& Broadley, M. R. (2012a). Agronomic biofortification of maize with selenium $(\mathrm{Se})$ in Malawi. Field Crops Research, 125, 118-128.

Chilimba, A. D. C., Young, S. D., Black, C. R., Meacham, M. C., Lammel, J., \& Broadley, M. R. (2012b). Assessing residual availability of selenium applied to maize crops in Malawi. Field Crops Research, 134, 11-18.

Chilimba, A. D. C., Young, S. D., Black, C. R., Rogerson, K. B., Ander, E. L., Watts, M. J., et al. (2011). Maize grain and soil surveys reveal suboptimal dietary selenium intake is widespread in Malawi. Scientific Reports, 1, 72.

Combs, G. F. (2001). Selenium in global food systems. British Journal of Nutrition, 85, 517-547.

Crout, N. M. J., Tye, A. M., Zhang, H., Mcgrath, S. P., \& Young, S. D. (2006). Kinetics of metal fixation in soils: Measurement and modeling by isotopic dilution. Environmental Toxicology and Chemistry, 25, 659-663.

Curtin, D., Hanson, R., \& Van Der Weerden, T. J. (2008). Effect of selenium fertiliser formulation and rate of application on selenium concentrations in irrigated and dryland wheat (Triticum aestivum). New Zealand Journal of Crop and Horticultural Science, 36, 1-7.

Ducsay, L., \& Ložek, O. (2006). Effect of selenium foliar application on its content in winter wheat grain. Plant Soil and Environment, 52, 78-84.

Ebrahimi, N., Stoddard, F. L., Hartikainen, H., \& Seppänen, M. M. (2019). Plant species and growing season weather influence the efficiency of selenium biofortification. Nutrient Cycling in Agroecosystems, 114, 111-124.

Fairweather-tait, S. J., Bao, Y., Broadley, M. R., Collings, R., Ford, D., Hesketh, J. E., \& Hurst, R. (2011). Selenium in human health and disease. Antioxidants and Redox Signaling, 14, 1337-1383.

Fan, J., Wang, R., Hu, H., Huo, G., Fu, Q., \& Zhu, J. (2015). Transformation and bioavailability of selenate and selenite added to a Nicotiana tabacum L. planting soil. Communications in Soil Science and Plant Analysis, 46, 1362-1375.

Galinha, C., Freitas, M. C., Pacheco, A. M. G., Coutinho, J., Maçãs, B., \& Almeida, A. S. (2012). Determination of selenium in bread-wheat samples grown under a Se-supplementation regime in actual field conditions. Journal of Radioanalytical and Nuclear Chemistry, 291, 231-235.

Gissel-Nielsen, G., Gupta, U. C., Lamand, M., \& Westermarck, T. (1984). Selenium in soils and plants and its importance in livestock and human nutrition. Advances in Agronomy, 37, 397-460.
Gissel-Nielsen, G., \& Hamdy, A. A. (1977). Leaching of added selenium soils low in native selenium. Journal of Plant Nutrition and Soil Science, 140, 193-198.

Gupta, U. C., \& Winter, K. A. (1989). Effect of selenate vs selenite forms of selenium in increasing the selenium concentration in forages and cereals. Canadian Journal of Soil Science, 69, 885-888.

Gupta, U. C., Winter, K. A., \& Sanderson, J. B. (1993). Selenium content of barley as influenced by selenite and selenate-enriched fertilizers. Communications in Soil Science and Plant Analysis, 24, 1165-1170.

Hashmi, A. A., \& Shafiullah. (2003). NASSD background paper: Agriculture and food security. IUCN Pakistan, Northern Areas Programme, Gilgit. https://portals.iucn. org/library/sites/library/files/documents/2003-095_1.pdf.

Hussain, T. (2001). Food composition table for Pakistan. Islamabad, Pakistan. http://www.fao.org/fileadmin/ templates/food_composition/documents/regional/Book_ Food_Composition_Table_for_Pakistan_.pdf.

Iqbal, S., Kazi, T. G., Bhanger, M. I., Akhtar, M., \& Sarfraz, R. A. (2008). Determination of selenium content in selected Pakistani foods. International Journal of Food Science and Technology, 43, 339-345.

Joy, E. J. M., Broadley, M. R., Young, S. D., Black, C. R., Chilimba, A. D. C., Ander, E. L., et al. (2015a). Soil type influences crop mineral composition in Malawi. Science of the Total Environment, 505, 587-595.

Joy, E. J. M., Kumssa, D. B., Broadley, M. R., Watts, M. J., Young, S. D., Chilimba, A. D. C., \& Ander, E. L. (2015b). Dietary mineral supplies in Malawi: Spatial and socioeconomic assessment. BMC Nutrition, 1, 42.

Karlson, U., \& Frankenberger, W.T. Jr. (1990). Volatilization of selenium from agricultural evaporation pond sediments. Science of the Total Environment, 92, 41-54.

Keskinen, R., Ekholm, P., Yli-Halla, M., \& Hartikainen, H. (2009). Efficiency of different methods in extracting selenium from agricultural soils of Finland. Geoderma, 153, 87-93.

Li, H. F., Mcgrath, S. P., \& Zhao, F. J. (2008). Selenium uptake, translocation and speciation in wheat supplied with selenate or selenite. New Phytologist, 178, 92-102.

Ligowe, I. S., Phiri, F. P., Ander, E. L., Bailey, E. H., Chilimba, A. D. C., Gashu, D., Joy, E. J. M., Lark, R. M., Kabambe, V., Kalimbira, A. A., Kumssa, D. B., Nalivata, P. C., Young, S. D., \& Broadley M. R. (2020a). Selenium (Se) deficiency risks in sub-Saharan African food systems and their geospatial linkages. Proceedings of the Nutrition Society, 79, 457-467. https://doi.org/10.1017/ s0029665120006904.

Ligowe, I. S., Young, S. D., Ander, E. L., Kabambe, V., Chilimba, A. D. C., Bailey, E. H., et al. (2019). Agronomic biofortification of leafy vegetables grown in an Oxisol, Alfisol and Vertisol with isotopically labelled selenium $\left.{ }^{77} \mathrm{Se}\right)$. Geoderma, 361, 114106.

Ligowe, I. S., Young, S. D., Ander, E. L., Kabambe, V., Chilimba, A. D. C., Bailey, E. H., et al. (2020). Selenium biofortification of crops on a Malawi Alfisol under conservation agriculture. Geoderma, 369, 114315.

Lopes, G., Ávila, F. W., \& Guilherme, L. R. G. (2017). Selenium behavior in the soil environment and its implication for human health. Ciência e Agrotecnologia, 41, 605-615. 
Lyons, G. H., Lewis, J., Lorimer, M. F., Holloway, R. E., Brace, D. M., Stangoulis, J. C. R., \& Graham, R. D. (2004). Highselenium wheat: agronomic biofortification strategies to improve human nutrition. Food, Agriculture and Environment, 12, 171-178.

Mao, H., Wang, J., Wang, Z., Zan, Y., Lyons, G., \& Zou, C. (2014). Using agronomic biofortification to boost zinc, selenium, and iodine concentrations of food crops grown on the loess plateau in China. Journal of Soil Science and Plant Nutrition, 14, 459-470.

Mathers, A. (2015). Modelling the fate of selenium added to soil to improve biofortification efficiency. Ph.d., thesis. University of Nottingham.

Mathers, A. W., Young, S. D., Mcgrath, S. P., Zhao, F. J., Crout, N. M. J., \& Bailey, E. H. (2017). Determining the fate of selenium in wheat biofortification: an isotopically labelled field trial study. Plant and Soil, 420, 61-77.

Moreno, G. R., Burdock, R., Díaz Álvarez, M. C., \& Crawford, J. W. (2013). Managing the selenium content in soils in semiarid environments through the recycling of organic matter. Applied and Environmental Soil Science, 2013, 283468.

Peng, Q., Wang, M., Cui, Z., Huang, J., Chen, C., Guo, L., \& Liang, D. (2017). Assessment of bioavailability of selenium in different plant-soil systems by diffusive gradients in thin-films (DGT). Environmental Pollution, 225, 637-643.

Rasul, G., \& Hussain, A. (2015). Sustainable food security in the mountains of Pakistan: Towards a policy framework. Ecology of Food and Nutrition, 54, 625-643.

Rayman, M. P. (2000). The importance of selenium to human health. The Lancet, 356, 233-241.

Rayman, M. P. (2008). Food-chain selenium and human health: emphasis on intake. British Journal of Nutrition, 100, 254-268.

Rayman, M. P. (2012). Selenium and human health. The Lancet, $379,1256-1268$.

Raza, A. (2018). Pakistan: Grain and feed annual. https://www. fas.usda.gov/data/pakistan-grain-and-feed-annual-3. Accessed on 18 July 2020.

Rehman, A., Jingdong, L., Shahzad, B., Chandio, A. A., Hussain, I., Nabi, G., \& Iqbal, M. S. (2015). Economic perspectives of major field crops of Pakistan: An empirical study. Pacific Science Review B: Humanities and Social Sciences, 1, 145-158.

Ros, G. H., Van Rotterdam, A. M. D., Bussink, D. W., \& Bindraban, P. S. (2016). Selenium fertilization strategies for bio-fortification of food: an agro-ecosystem approach. Plant and Soil, 404, 99-112.
Rowell, D. L. (1994). Soil science methods and applications. London: Longman.

Stephen, R. C., Saville, D. J., \& Watkinson, J. H. (1989). The effects of sodium selenate applications on growth and selenium concentration in wheat. New Zealand Journal of Crop and Horticultural Science, 17, 229-237.

Stroud, J. L., Broadley, M. R., Foot, I., Fairweather-Tait, S. J., Hart, D. J., Hurst, R., et al. (2010). Soil factors affecting selenium concentration in wheat grain and the fate and speciation of Se fertilisers applied to soil. Plant and Soil, 332, 19-30.

Tinggi, U. (2008). Selenium: Its role as antioxidant in human health. Environmental Health and Preventive Medicine, 13, 102-108.

USDA (United States Department of Agriculture). Agricultural Research Service, Food Data Central. (2019). http://fdc. nal.usda.gov.

Wang, Q., Yu, Y., Li, J., Wan, Y., Huang, Q., Guo, Y., \& Li, H. (2017). Effects of different forms of selenium fertilizers on Se accumulation, distribution, and residual effect in winter wheat-summer maize rotation system. Journal of Agricultural and Food Chemistry, 65, 1116-1123.

White, P. J. (2016). Selenium accumulation by plants. Annals of Botany, 117, 217-235.

White, P. J., \& Broadley, M. R. (2009). Biofortification of crops with seven mineral elements often lacking in human diets-iron, zinc, copper, calcium, magnesium, selenium and iodine. New Phytologist, 182, 49-84.

WHO (World Health Organisation). (2019). Biofortification of staple crops. https://www.who.int/elena/titles/ biofortification/en/ Accessed 15 Mar 2019.

Yang, R., Liu, Y., \& Zhou, Z. (2017). Selenium and selenoproteins, from structure, function to food resource and nutrition. Food Science and Technology Research, 23, 363-373.

Zhang, Z., Liu, Q., Yang, J., Yao, H., Fan, R., Cao, C., et al. (2020). The proteomic profiling of multiple tissue damage in chickens for a selenium deficiency biomarker discovery. Food \& Function, 11, 1312-1321.

Zia, M. H., Watts, M. J., Gardner, A., \& Chenery, S. R. (2014). Iodine status of soils, grain crops, and irrigation waters in Pakistan. Environmental Earth Sciences, 73, 7995-8008.

Publisher's Note Springer Nature remains neutral with regard to jurisdictional claims in published maps and institutional affiliations. 